\title{
人工股関節テンプレートの拡大率についての検討
}

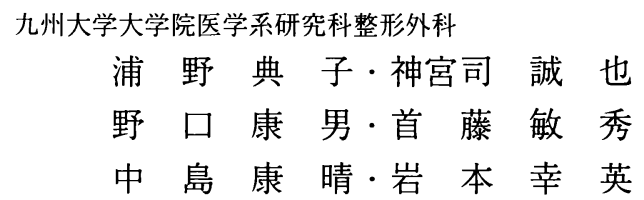

\section{Magnification of Templating Scale for Components of Total Hip Arthroplasty}

\author{
Noriko Urano, Seiya Jingushi, Yasuo Noguchi, \\ Toshihide Shuto, Yasuharu Nakashima, and Yukihide Iwamoto \\ Department of Orthopaedic Surgery, \\ Graduate School of Medical Shool, Kyushu University
}

\begin{abstract}
Hip joints in radiographs were magnified in order to examine the appropriate magnification of templates for preoperative planning in total hip arthroplasty (THA). The magnification of each hip joint, in postoperative radiographs after THA, was calcurated using inserted implants (socket or femoral stem) as scales. The relationship between the magnifications and grade of obesity or hip flexion contracture was also examined. In most hips, the percentage of magnification was between 110 and 120 . Obesity or hip flexion contracture did not influence the magnification. These date suggest that degrees above $110 \%$ are more appropriate than $110 \%$ for the magnification of templates.
\end{abstract}

Key words : Total Hip Arthroplasty (人工股関節全置換術), Preoperative Planning (術前 計画)

はじめに

人工股関節置換術の術前計画において通常 $10 \%$ 拡 大したテンプレートが用いられている。しかしながら, 術後レントゲン写真におけるコンポーネントの大きさ が同サイズのテンプレートと合わないことをしばしば 経験する，そこで，人工関節そのものをスケールとし て拡大率を算出し，テンプレートの拡大率が適当であ るか検討した。

\section{対象と方 法}

1998 年 4 月から 1999 年 3 月に Kyocera Perfix を用い，セメントレス人工股関節置換術を施行された 37 例（男性 4 例，女性 33 例）を対象とした。手術時 平均年齢は, 68.9 歳（39〜82 歳）であった。原疾患
は, 变形性股関節症 31 例, 大腿骨頭壊死 2 例, 慢性 関節リウマチ 2 例, 急速破壊型股関節症 1 例, 強直性 関節炎に伴う股関節症 1 例であった。

レントゲン写真の拡大率は人工関節をスケールとし て測定，算出した，具体的には，術後仰臥位における 両股関節正面像にて臼蓋ソケット直径と大腿骨ステム 長（図 1) を測定し,カルテの記載より調査した実際 の各々の長さとの割合を計算し, 拡大率とした.

また，拡大率に影響を与えうる因子として，肥満， 股関節の屈曲拘縮の程度を考え, それとの相関につい て検討した。肥満率は，入院時の身長，体重から Body Mass Index（体重/身長 ${ }^{2}$ )を算出した。屈曲 拘縮の程度は，仰臥位における骨盤傾斜を指標とし， 骨盤腔のタテヨコ比（図 2）を算出した。管球からフィ ルムまでの距離は常に一定で撮影されていた。 


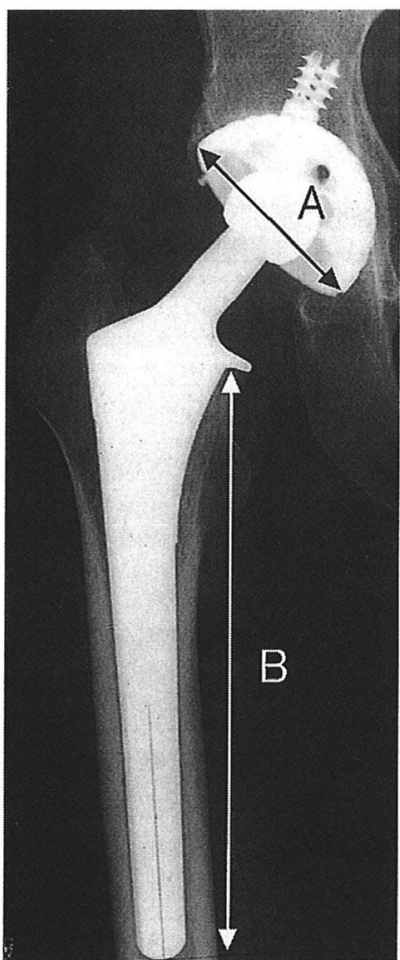

図 1 人工股関節における測定部位 A：ソケット直径 B：ステム長

結

果

ソケット拡大率は平均 $116.5 \%(101.8 \sim 128 \%)$ ， ス テム拡大率は平均 $116.4 \%(105.6$ 135.6\% ）であっ た. $5 \%$ 増毎に症例数を数え分布を調べると、ソケッ 卜拡大率では $115 \%$ 以上 $120 \%$ 未満が最も多く，全体 の $68 \%$ を占めていた，ステム拡大率では $110 \%$ 以上 $115 \%$ 未満が全体の $43 \% ， 115 \%$ 以上 $120 \%$ 未満が $41 \%$ であった. すなわち、ソケット拡大率およびス テム拡大率ともほとんどの症例が拡大率 $110 \%$ 以上 120\% 未満に分布していた（図3）.

肥満率に関わらず拡大率は $110 １ 20 \%$ の間に多く 分布しており，拡大率と肥満率に関連性は認められな かった（図 4)。また，拡大率と骨盤内腔夕テヨコ比 にも関連性は認められなかった（図 5).

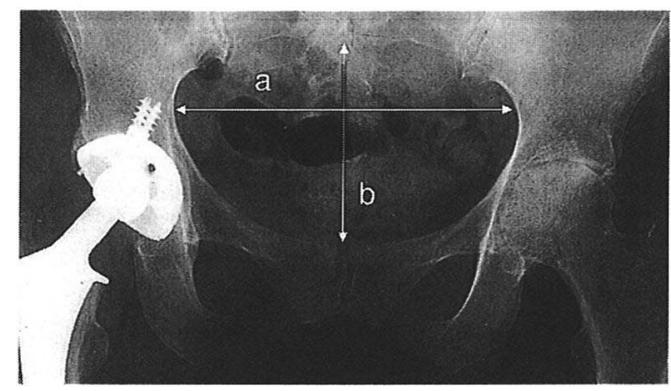

図 2 股関節の屈曲拘縮の程度 $\mathrm{a} ：$ 骨盤腔ヨコの長さ b : 骨盤腔夕テの長さ 骨盤内腔夕テヨコ比 $=b / a$

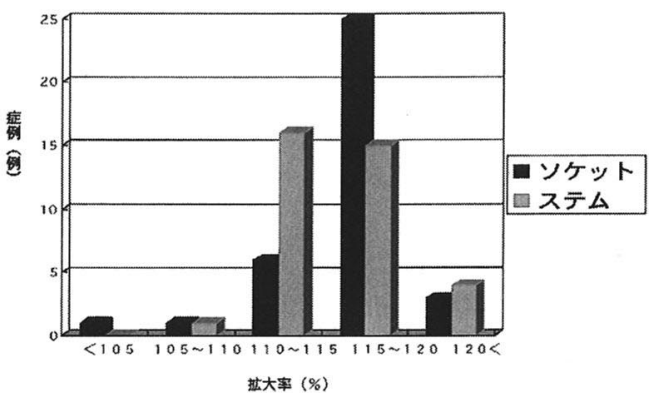

図 3 術後レントゲン写真における人工股関節拡大率 分布

ほとんどの症例が $110 \%$ 以上 $120 \%$ 未満に分布 している。

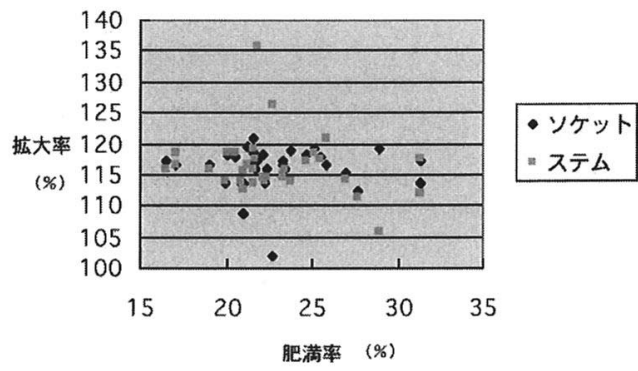

図 4 拡大率と肥满率 関連性は認められなかった 


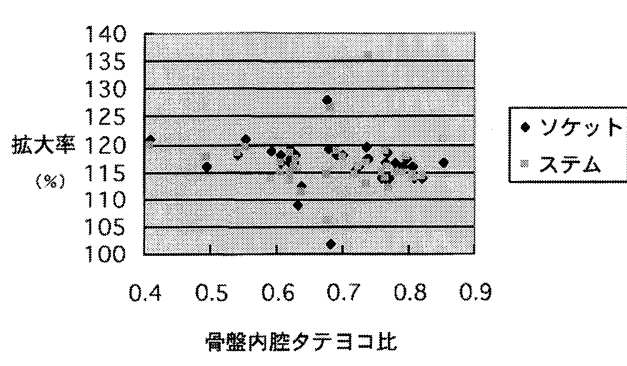

図 5 拡大率と骨盤内腔タテヨコ比 関連性は認められなかった。

\section{考察}

本調査結果をもとに，10\%テンプレートを用いて どの程度適当な術前計画ができるか検討してみた（表 1)。例えばステムの実直径が $14 \mathrm{~mm}$ の場合，レント ゲン写真に拉ける拡大が $110,115 ， 120 \%$ であったと するとステムの直径は各々 $15.4,16.1,16.8 \mathrm{~mm}$ と なる. $110 \%$ 拡大テンプレートにおけるひとつ上のサ イズ $(15 \mathrm{~mm})$ のステムが $16.5 \mathrm{~mm}$ であり，レント ゲン写真が $120 \%$ 拡大であった場合, $110 \%$ 拡大テン プレートを用いて術前計画を行うとひとつ上のサイズ のステムが選択されることになり実際と異なる。この ように考えていくと $110 \%$ テンプレートを用いた場合， 適当なサイズのステムを選択しうるレントゲン写真の 拡大率は扰打よそ105１15\% ということになる。本 調査で測定した拡大率をあてはめてみると $110 \%$ 拡大 テンプレートで適当なサイズが予想される確率は，ス テムで $46 \%$ ，ソケットでは $19 \%$ と低い結果となった。

テンプレートの拡大率を変化させ，さきほど示した 考え方で各拡大率のテンプレートで適当なサイズを選 択できる確率を算出してみた（表 2)，我々の症例で は， $115 \%$ から $117 \%$ 拡大テンプレートの方が適当な サイズを選択できる確率が高かった。

今回検討した症例の中で大腿骨ステムのみが高い拡 大率を示す症例があった。同症例は同側膝関節の屈曲 拘縮があり，大腿骨がフィルムより遠くなるために大 腿骨ステムのみが高い拡大率を示したと考えられた。 膝関節屈曲拘縮の影響をなくすためには腹臥位撮影が 適当かもしれない.

肥満は屈曲拘縮の程度との相関性はなく, ほとんど の症例が 110 120\%の拡大率であった。適当な拡大 率のテンプレートを用いれば個人差はほとんどなく適
表 1 コンポーネントサイズ別の各拡大率におけ るレントゲン写真上でのステム直径

\begin{tabular}{ccccc}
\hline \multirow{2}{*}{ 拡大率 } & \multicolumn{3}{c}{ コンポーネントサイズ } \\
\cline { 2 - 5 } & 14 & 15 & 16 & 17 \\
\hline $105 \%$ & 14.7 & 15.7 & 16.8 & 17.8 \\
$110 \%$ & 15.4 & 16.5 & 17.6 & 18.7 \\
$115 \%$ & 16.1 & 17.2 & 18.4 & 19.5 \\
$120 \%$ & 16.8 & 18.0 & 19.2 & 20.4 \\
$125 \%$ & 17.5 & 18.7 & & \\
$130 \%$ & 18.2 & 19.5 & & \\
\hline
\end{tabular}

$110 \%$ テンプレートを用いた際に至適サイズとは 異なるサイズが選択されうるレントゲン写真上で の実測値を四角で囲んだ。

表 2 拡大率の異なるテンプレートにて至適コン ポーネントが選択されると考えられる確率

\begin{tabular}{c|c|c}
\hline \hline 拡大率 & ステム & ソケット \\
\hline $110 \%$ & $46 \%$ & $19 \%$ \\
$111 \%$ & $54 \%$ & $32 \%$ \\
$112 \%$ & $59 \%$ & $49 \%$ \\
$113 \%$ & $70 \%$ & $65 \%$ \\
$114 \%$ & $81 \%$ & $76 \%$ \\
$115 \%$ & $\underline{89 \%}$ & $\underline{81 \%}$ \\
$116 \%$ & $\underline{89 \%}$ & $\underline{82 \%}$ \\
$117 \%$ & $\underline{89 \%}$ & $\underline{82 \%}$ \\
$118 \%$ & $81 \%$ & $81 \%$ \\
$119 \%$ & $70 \%$ & $70 \%$ \\
\hline
\end{tabular}

テンプレートの拡大率を変化させた際に適当なサ イズが選択される確率を算出した.

当なサイズのコンポーネントを選択できると思われる.

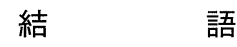

(1)人工股関節テンプレートの拡大率について検討し た。

(2)術後レントゲン写真におけるソケットおよびステ 厶拡大率が $110 \%$ テンプレートでは合わない症例が多 かった.

(3)肥満や屈曲拘縮とは関連性が認められなかった。

(4)テンプレート拡大率を変更した方がより適当な術 前計画が可能になると思われた。 


\section{参 考 文 献}

1) Gorski, J. M., Schwartz, L.: A device to measure
$\mathrm{X}$-ray magnification in preoperative planning for cementless arthroplasty. Clin Orthop, 202: 302-306, 1986. 